\section{The \\ nightmare \\ before \\ funding}

\section{研究助成金を \\ 受け取るまでの}

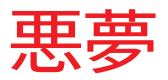

Nature Vol.437(308-311)/15 September 2005

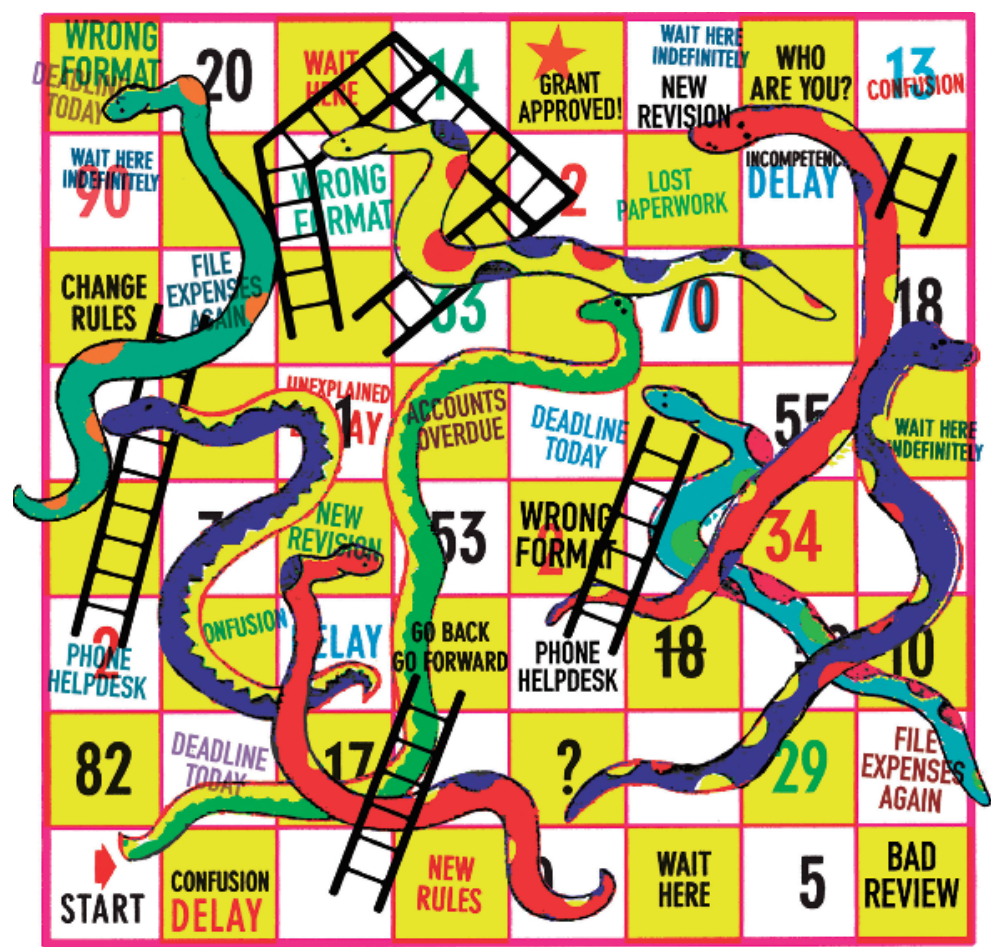

自分の仕事の嫌なところを 1 つ挙げてもらうと、研究助成金の申請手続きだという科学者が多い。この手続きがそれ ほどに挫折感を抱かせるのはなぜか。どうすれば事態は改善されるのか。Nature の記者たちが研究者に問いかけた。

物理学者は腹が立つというし、細胞生 物学者は頭にくるという。それが理由 で科学研究をやめたいと考える研究者 もいる。どの分野の研究者も「研究資 金提供機関への研究助成金の申請には 時間がかかり、ストレスを感じる」と 語る。多くの研究者にとって、それは 仕事における最悪の部分なのだ。

Nature の記者たちが、研究者を対象 に研究助成金申請に関する聞き取り調 査をはじめて約 1 年が経った。なかに はちょっとした怖い話もあったが、私 たちにとって意外感はなかった。話を したがらない研究者も多かった。それ が研究資金を提供してくれる人々の「手 をかむ」結果になるのだから無理もな い。話をしてくれた研究者からは、重 なる遅延、ややこしい申請書、お役所 仕事によってみずからのキャリアが狂 わされかけたことなどが聞けた。今回 の記事では、とりわけ啓発的な話、そ して助成金申請にともなう苦労をやわ
らげる方法について、研究者や研究資 金提供機関の意見を集めた。

時間の浪費が、最も多い苦情だっ た。欧州、アジア、米国の研究者は、 いずれも研究助成金の支給の遅れによ るフラストレーションを経験してい る。特筆すべきは、ドイツの大学で化 学を研究する Jens Schmidt の事例だ。 Nature のインタビューに答えてくれた ほとんどの研究者と同様に、彼も仮名 での紹介を条件としている。

ドイツ連邦教育科学研究技術省によ れば、研究助成金申請の平均処理期間は 6 か月だという。ところが、Schmidt の経験はちがっていた。彼の申請は、 当初の審査時から高い評価を受けてい たのに、実際に助成金が給付されたの は 2 年半後のことだった。

Schmidtの申請にまつわる長いス トーリーは、環境科学研究プロジェク トのため 15 万ユーロ（約 2100 万円） の研究助成金申請の概要書を提出した
2000 年 4 月にはじまった。それに対 する回答が届いたのは 8 か月後だった。 審査結果は良好で、ついては2001年 の初頭に正式申請を提出するようにと いうものだった。その次の返事は 2001 年の 10 月になってようやく届いたが、 審査官はやはり研究プロジェクトに熱 意を示していた。もしかすると、その 熱意がやや強すぎたのかもしれない。

審査結果がよかったため、Schmidt は、プロジェクトの実施期間を当初提 案した 2 年から 3 年に延長するように 要請された。2002 年の初めに、実施期 間を延長した第 3 次申請書を提出した ところ、なんと今度は教育科学研究技 術省から 3 年間分のプロジェクトに十

\ 『NERC という言葉がタブー ワ なのも、もっともなことです 自然環境研究会議（NERC）に対する研 究助成金申請を却下された英国の研究者 の気持ちだ。 
分な予算を出せないという指摘を受け た。そこで、当然のことながらプロジェ クトの規模を縮小した第 4 の申請書を 提出し、2002 年 10 月になってやっと 実際に助成金が給付された。Schmidt が以前に購入していたノートパソコ ンは、そのころには研究に必要なソフ トウェアを作動させるには能力不足に なっていた。ただ幸いなことに、彼の 発想は時代遅れになってはいなかった。

助成金申請をめぐる苦情で次に多い のは、助成金の使い道の会計報告にと もなう手続き的負担についてである。 研究者は、不正行為を防ぐために会計 報告が必要だと認識してはいるが、担 当官庁がまるで大局観をもたずに使途 を監視することが多い点を指摘する。

\section{細かく釈明を求める}

お役所仕事で悪名の高いフランスの研 究機関と大学では、実験用試薬といった 基本品目の購入についてまでも、比較の ための見積りを要求することが多い。面 倒な会計報告書は、研究者を混乱に陥 れている欧州連合（EU）の研究助成金 制度における問題の 1 つにすぎない(コ ラム「書類、書類、また書類」参照)。

過度に詳細な会計報告という点では、 日本の右に出る国はないようだ。たとえ ば、厚生労働省から研究補助金を受け 取っている研究者は、3524 円の 445 ページにおよぶガイドブック (『厚生労 働省科学研究費の手引』）を毎年購入し て、同省の最新の会計規則を把握しな ければならない。また、文部科学省は、 ある年に給付された研究助成金は、地 震のような予測不能の事態による遅延 を除き、その年のうちに使いきること を要求する。使われなかった助成金は 返還しなければならない。

東京大学大学院で生物化学を研究す る多比良和誠教授（本人の快諾により 実名）は最近、日本のお役所仕事がい かにさまつなものであるかに気づいた。 昨年、彼は 5000 万円の政府補助金を 受け取った。日本の研究機関の独立性 を増進させる方針のもと、研究補助金
の管理は東京大学に委託されたのだが、 奇怪な結果となってしまった。多比良 教授の秘書が、研究室の事務に使用す るペンと消しゴムの購入を大学の事務 局に願い出たところ、これらの消耗品は 補助金と関係することにしか使っては ならないという指示を受けたのだった。 大学側はそのような事実はなかったと し、研究者がすでにペンを持っていたの で「重なって購入する事態を避けたかっ た」と述べた。いずれにせよ、常識より も不条理な経理がまかり通るのだ。

\section{5}

日本の厚生労働省から給付される研究補 助金に関する予算規則を記したガイド ブック (年刊) の総ページ数。

このような恣意的な規則はため息で すむかもしれないが、もし助成金給付 決定に不備があれば、事態はもっと深 刻になる可能性がある。ほとんどの研 究者は、キャリアを続けるために競争 的な研究助成金を獲得しなければなら ない。もし出願過程の管理に不手際が あると、何の落ち度もなかった申請者 が論文競争に敗れ、極端な場合には、 その研究分野にいられなくなることも あるのだ。

Hugh Roberts（仮名）の場合には、 すんでのところで研究を続けられなく なるところだった。Roberts は英国を 拠点とする免疫学の研究者だったが、 昨年、キャリアにかかわる厳しい決断 を迫られた。8 年間のポスドク研究生活 で彼は、一流の国際誌に複数の研究論 文を発表し、高い評価を受けていた。「私 の履歴書は、けっして他の研究者に引 けを取っていません」と彼は語る。と ころが、グループリーダーへ昇格する ところで、大きな壁にぶつかったのだっ た。いくつかの英国の研究資金提供機 関は、そのためのキャリア形成助成金 を給付していたが、ポスドク研究員の 経験年数が 6 年以下というのが受給資 格だった。Robertsは34歳になって
いたが、それでも自分は若手の研究者 だと思っていた。「それなのに、研究者 として峠を越していると告げられたよ うなものだった」。

そのうち解決策らしきものがみえて きた。英国の医学研究会議 (MRC) は 生物医学の研究プロジェクトに対する 英国政府予算のほとんどを配分する機 関だが、その助成金制度の 1 つで、ポ スドク研究年数の制限が撤廃されたの だ。これによって Roberts は 3 年間で 総額 25 万ポンド（約 5200 万円）の 助成金申請が可能になり、それを使っ て研究室を開設する計画を立てた。彼 が所属する大学は、彼の雇用の継続に 積極的で、給料の支払いにも同意した。 ところがMRCは、申請数を減らすた めに 1 つの大学からの申請者を 3 人に 制限した。このため、Roberts の大学 では学内での競争を行い、8ページの 提案書の提出と 10 分間の口頭説明を課 した。彼はこの競争に勝利し、5月に MRC に申請書を提出した。「ほぼ 1 か 月間、断続的にですが、そのための作 業がメインになってしまった」という。

10 月になって Robertsは、研究助 成金の受給者に選ばれなかったことを 告げられたが、冷静さを保っていた。 受給対象が 20 のところに、120を超 える申請があったことを知っていたか らだ。「厳しい結果ですが、このような 状況では負けてもしかたがないと思い ました」。ところが、その後 MRC から の落選通知を受け取ったRobertsは、 落選の理由を知って愕然とした。決め 手になったのは、1人の研究者による 1 通の評価書だった。われわれもこの 評価書の写しを見せてもらったが、評 価を下したこの研究者は、彼の研究分 野では多数説となっていない見方を強 硬に主張している研究者だった。この 落選決定に対する異議申立てができず、 RobertsはMRCに裏切られたという 感じをもっている。「MRCは、私の研 究を本気で審査するつもりはなかった のだと思う」。 


\section{見捨てられたという思い}

会計規則、お役所仕事による遅延といっ た話は、このRoberts の落胆に比べれ ば些細なことにすら思える。MRCの審 査過程を非難する落選者はRoberts が 初めてではないだろうが、通常の 3 人 の審査ではなく、1 人だけですませた MRCには判断の誤りがあったと思われ る。1 人の審査員による査読で申請が却 下されるのは非常にめずしいことだと、 助成金給付審査委員会に参加している 複数の研究者も確認している。MRC
ンドン事務所のプログラム担当マネー ジャーPeter Dukes は、今回の事例は 「われわれの仕事の水準」を示す典型例 ではない、と強く主張する。

ただ、Robertsの場合にはハッピー エンドが待っていた。彼はその後、大 学でのポジションを得て、研究室を開 設することができたのだ。助成金申請 書に概説された研究の一部は完了し、 いくつかの著名な国際誌に掲載された。 それでも Robertsは、「MRCへの申請 が却下されたときには、科学研究をや

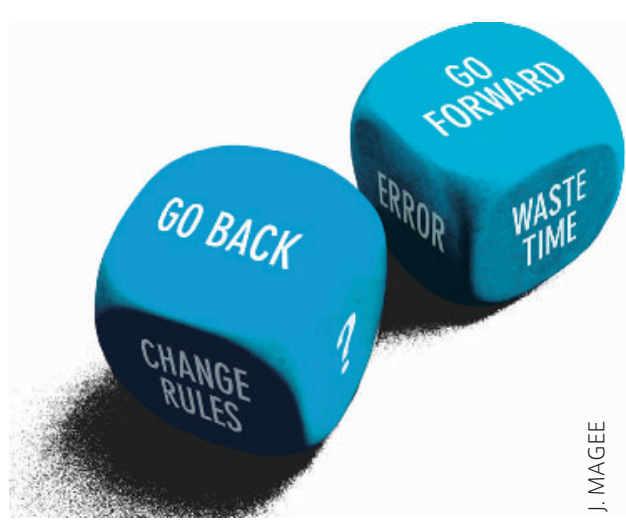

\section{書類、書類、また書類}

一番たいへんな研究助成金申 請制度はどれだったかと研究者 に尋ねたところ、同じ名前が何 度も聞かれた。総額 175 億ユ一 口（約 2 兆 4500 億円）の欧 州委員会第 6 次フレームワー ク・プログラム (Framework Programme) である。

この助成金に申請したこと のある研究者たちは、「ありと あらゆる研究助成金制度のな かで、申請手順が最もまぎら わしく煩雑だ」と語る。膨大 な量の文書作成はまるで悪夢 で、緻密な文言と複雑な申請 要件を理解するために、超人 的な頭脳の働きが求められる。 これは、実験系研究者よりも 政治家のニーズに合わせた巨 大な共同体がもとになって築 き上げられた制度であり、抜 本的な改革の手など届かない のかもしれない。

どのタイプの研究助成金を 申請するかを決めるだけで も大変な作業だ。総額数百万 ユーロの統合型プロジェクト (Integrated Project) はどう だろうか。ここでは、5つの夕 イプの統合型からどれかを選 ぶことができるが、どれも複 雑でわかりにくい。たとえば 「垂直統合型」は、「知識生産
から技術開発、技術移転にい たる各過程における利害関係 者の『バリューチェーン』全体」 に関係すると説明されている。

次に、申請対象の研究プロ ジェクトとはほとんど関係が ないような情報を、大量の書 式に記入しなければならない。 たとえば生命科学研究に対す る助成金の場合、その研究が ジェンダー問題とどう関連す るかの説明が求められる。だ が、「無性生殖微生物に関する 基礎分子生物学的研究にジェ ンダー問題をからめろといわ れてもむずかしい」と、ある オランダの研究者は指摘する。

これとは別に一筋縄ではい かないのが、研究者、実業家、 社会学者が参加する国際的で 学際的な共同研究体を形成す るため、必要な複数のパート ナーを探し、声をかけて集め ることである。これらに加え てさらに、整合性のある科学 研究計画を策定しなければな らないのだ。

どうしてこのような制度が できたのだろうか。その答え は、フレームワーク・プログ ラムの背後にひそむ政治的理 由にある。このプログラムは、 科学研究に資金を提供するの
ではなく、欧州連合（EU）の 政策目標を支援するのが目的 だったのだ。確かにすべての 研究機関が何らかの有力政治 家と結びついているものだが、 欧州の政治家とフレームワー ク・プログラムとの結びつき はとくに緊密なのだ。

$$
\text { そのためフレームワーク }
$$

プログラムは、いろいろな方 向に引きずられる。たとえば 直接選挙によって選ばれる欧 州議会の議員のみならず、EU 加盟国の各大臣も、フレーム ワークの構造や研究テーマを 承認する必要がある。研究の 優先順位も国益を追求する各 国によって決められている。 そして世の中のすべての障害 を取り除きたいという政治家 の欲望を満たすため、ジェン ダーによる差別といった広範 な社会問題の解決にフレーム ワーク・プログラムがー役買 わなければならない。

過去に何度も財務スキャン ダルが起こっている欧州委員 会は、さらなる事務手続きを 新設して、財務管理の不備と いう非難を受けないようにし ている。そのため研究者は、各 プロジェクトの詳細な財務文 書を事前に提出し、さらに実
際の経費記録を事後的に提出 することが求められる。国内の 研究助成金であれば、研究者 を信用して助成金が先に支払 われるのが通常で、詳細な会 計報告はプロジェクト終了後 でよい。

事態は改善するだろうか。 欧州委員会の官僚たちは問題 点を認識してはいるが、大規 模な改革が行われることを楽 観視する者はほとんどいない。 数多くの研究者はいま、基礎 研究のために設立される予定 の欧州研究評議会 (European Research Council) に望みを 託しているという。これは新た な研究資金提供機関で、2007 年からはじまる次期フレーム ワーク・プログラムの一角を なす。欧州研究評議会はこれ までよりも事務手続きを簡素 化し、年間最大 15 億ユー $\square$ (約 2100 億円）を研究者個人に分 配する計画になっている。と はいえ、欧州における研究費 補助制度のほとんどは、これ からも不恰好なほど巨大化し た共同体組織が担っていくの であり、研究者の憤りが静ま ることはないだろう。

\section{Alison Abbott}


めようと考えたこともあった」と当時 を振り返る。お役所仕事の誤りで、英 国から 1 人の才能ある研究者のが失わ れるところだったわけだ。

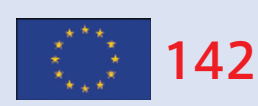

EU のフレームワーク・プログラムに対 する申請者が申請手続きに入る前に読む ことを推奨されている 6 種類の文書の総 ページ数。

\section{よりよい方法とは}

研究者としては、査読審査を受けるとい うたいへんさを経ずに、研究助成金を受 け取ることができればと願うこともある だろう。とはいえ、実際に査読審査なし に公的な研究資金を分配することに賛 成する者もいないだろう。研究資金提供 機関は、研究者に対し、その発想が正当 なものであることを証明させ、助成金を 受け取るにふさわしい者が必ず資金を 受け取れるようにする必要がある。しか し、そのための労力はできるだけ少なく する必要もある。この記事で紹介した事 例のいくつかでも防止するには、いった いどうすればよいのだろうか。

多くの場合で、米国の研究資金提供 機関が先を行っている。1990 年代のな かば、全米科学財団は「ファストレーン (FastLane)」というオンライン申請方 法を導入した。この方法は、書式に形式 的問題があれば自動的に指摘するもの で、そのおかげで研究者の時間が節約で きるようになったとして賞賛された。米
国の他の研究資金提供機関も、同様のシ ステムを取り入れるようになっている。 最終的には、連邦政府系の研究資金提 供機関に対する申請は 1 つのウェブサ イトで行えるようになるだろう。英国の 複数の研究会議も昨年、類似したウェブ サイトを導入し、国内の研究者から好意 的に受けとめられている。ドイツの主た る研究資金提供機関である DFG も、類 似の方法を導入する予定だ。日本の一部 の省庁など、このような方法を模索して いない研究資金提供機関は、もはや仲間 はずれのようになりかけている。

このほかにも米国での先進的な動き、 とくに資金提供機関の職員がしばしば 学会に出席し、研究者と対話しているこ とへの評判が高まっている。たとえば、 気候学のある研究者は、英国を拠点と して活動し、英国の資金提供機関から 研究資金を受け取っているが、英国の 担当者よりも米国の資金提供機関の担 当者と会う機会のほうが多いと語る。

「外での勤務は、1 か月にせいぜい 2 〜 3 日です」とDukesも認めている。 英国のすべての研究会議は、研究助成 金よりもスタッフの活動費が厳しく抑制 されていることを彼は指摘する。その代 わりに MRCでは、組織内の改革によっ て現在のスタッフが外での勤務に費やす 時間を増やせないかどうかを模索してい る、とDukes は話す。「われわれはより よい運営を目指しています」と彼はいう。

しかし最も賞賛された改革は、研究 者が目を通さなければならない書式、 説明書やガイドラインの数を減らすこ

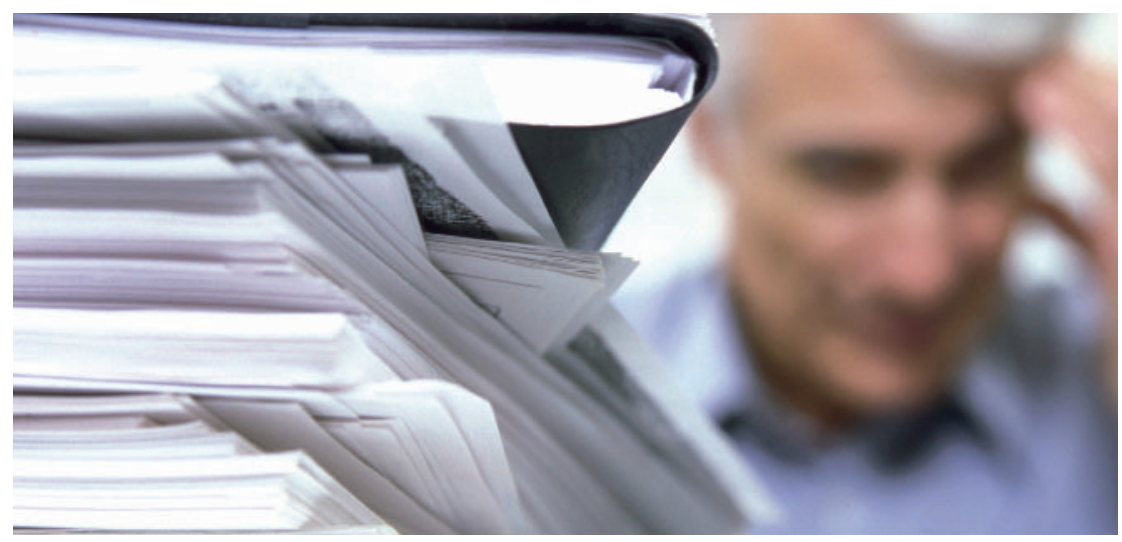

とだった。たとえばこの夏、米国の国 立衛生研究所 (NIH) は、6 年前に実施 した単純な制度変更の影響を評価した。 この変更では、25 万ドル（約 2800 万 円）未満の研究資金を申請する研究者 は、プロジェクトの内容の詳細といく ら資金が必要なのかを申告しなければ ならないが、詳細な会計文書について は、申請人の所属研究機関で事後的に 作成すればよいとされた。

この制度変更について、調査対象と なった研究者の $80 \%$ 以上は制度変更 に満足していると回答し、NIH で最も 申請者の多い研究助成金である R01に 対する申請者の約 4 分の 3 は、もは や事前に費用の詳細を提示しなくなっ た。査読者たちも、この制度変更はた いへんよかったと支持しており、この 変更によって、申請された研究の長所. 短所自体に集中して検討できるように なったと答えている。また、査読者た ちは、制度変更後は審査員として行動 する際の事務的負担が減ったと答えて おり、これが一番重要なことだったの かもしれない。

NIHのシステムに欠陷があるとすれ ば、それは申請書の長さだと複数の研 究者は語る。たとえば、R01の場合に は、研究概要書の総ページ数は 25 ペー ジである。これは上限であり、それよ りも短くても構わないと NIH の担当者 はいう。しかし、査読者の心証をよく するために、使えるスペースはフルに 使いたいと考えるのが申請者の行動心 理だろう。別の研究助成金を申請した ことがある研究者は、単純に書式の短 さが時間の節約につながると提案する。 たとえば英国では、R01に相当する研 究助成金を申請するための書式の長さ は最大 8 ページとなっている。

\section{「どの苦情ですか。どれも きっとこれまでに一度は聞 いたことがあると思います」}

NIH外部プログラム局のディレクター代行 Walter Schaffer は、研究者から寄せられ る苦情の幅広さをこのように説明する。 
用意されている研究助成金の種類に ついても、研究者は数が少ないほどよ いと答えている。MRC は最近、研究助 成金のタイプを減らす一方で制度を柔 軟化させ、たとえば研究者が受給期間 を選択して申請できるようにした。こ の新制度には好意的なフィードバック を得ているとDukesはいう。これと 対照的なのが日本で、助成金の種類は、 2004 年の 28 種類から 2005 年には 37 種類に増えている。

改革の成功例をみてみると、多くの場 合、その答えはシンプルだ。研究者が 求めているのは、オープンで利用しやす く、研究者の立場を理解しようと努力す る研究資金提供機関なのである。大学で
研究者の助成金申請手続きを支援して いる職員によれば、係員本人が電話で対 応するヘルプデスクを設置するだけで も大きなプラスになるという(コラム「研 究助成金申請事務の現場から」参照)。 また、研究資金提供機関のスタッフが学 会に参加したり、研究室を訪問したり、 あるいは集会を開いて、研究資金提供機 関の活動内容に関する意見を聞いたりす ることを研究者は好む。とりわけ研究者 が望んでいるのは、研究資金提供機関 が、そういったフィードバックに基づい て行動をとることだ。研究助成金の申請 は、研究者の仕事における苦労の種なの かもしれない。しかし、研究資金提供機 関がみずから苦労の種となる必要はな
いのだ。それにはどうすればよいか、研 究者の声に耳を傾け、対応している機関 はすでに気づいている。

Jim Giles は、Natureのシニアレポーター(ロンドン)。 取材協力: Andreas von Bubnoff（ワシント ン)、冬野いち子 (東京)、Tamara Gruener とValeskaStephan (ミュンヘン)、Declan Butler (パリ)

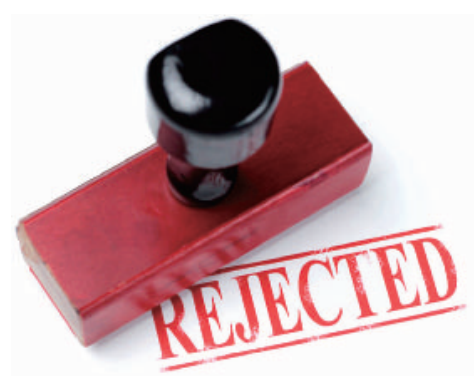

\section{研究助成金申請事務の現場から}

ワシントン大学 (米国シアトル) に勤める Karen Bergeron は、 20 年を超える研究助成金申請 事務の経験をもつ事務官だ。研 究助成金申請はおもしろい仕 事だ、と彼女はいう。

米国での研助成金申請手続き は、複雑になってきていますか ? 研究支援機関は、議会での予 算承認が厳しくなってきてい ることから、研究者に対して 研究の正当性を証明すること を求めています。研究者は、 自分のプロジェクトの知的価 值と応用範囲の幅広さを明確 に示す必要があります。研究 支援機関は、提案書の冒頭で まずそこをみたいのです。ど のような研究を行う計画であ るかを説明するだけでは足り ません。このような要求につ いて、多くの研究者が侮辱的 だと思っていることはわかっ ています。経過報告書を書き たくないのと同じ心情です。

楽になったのは、研究支援 機関が柔軟に対応するように なった点です。ひと昔前は、
助成金の使い道について計画 変更をしようとすれば、申請 しなおして承認を得る必要が ありました。今は、資金を受 け取ること自体がむずかしく なっていますが、いったん受 け取れば、使い道はかなり自 由にコントロールできるよう になっています。

米国では、どの研究支援機関 の助成金申請手続きに最も時 間がかかりますか?

国立衛生研究所 (NIH) だと思 います。提案書について、必 ず土壇場になってページ番号 や図表の修正といった手なお しがあるからです。NIHの記 載要領は、神経質なまでに細 かいのです。ホッチキスといっ た緅じこみ器具は使用禁止な のに、大型クリップや輪ゴム は使えます。フォントはArial か Helvetica、サイズは 10 ポ イント以上という決まりです。

私は「フォント警察 (font police)」とよばれるほどにな りました。先日、男性職員に 個人指導をしていたのですが、
まるで迷彩服を着た NIH 新兵 訓練所の教官が「これであな たも NIH 研究助成金申請書を 提出できるわよ」といっている みたいだとからかわれました。

全米科学財団 (NSF) が「ファ ストレーン (FastLane)」と いう形で、はじめて電子的投 稿を導入しました。役に立っ ていますか ?

はい、役立っています。ファス トレーンが導入される前は、提 案書の記載に不備があるだけ で、直ちに返送されてくること が珍しくありませんでした。あ る時、プロポーショナル・スペー シングを使った研究者がおり、 彼はそれで記載要件を満たし ていると思っていました。とこ ろが、NSF は定規を持ちだし て、1インチ当たりの字数が多 すぎることを発見したのです。 ファストレーンでは、そのよう な形式的なチェックの多くを自 動的に行ってくれます。

NSF のよいところはへルプ デスクがあることで、いつで も係員が対応してくれます。
自動応答電話を使っておらず、 おまけに係員はとても頭のよ い人たちです。人間の知能に 代わるものはありません。

たいていの研究者は研究助成 金申請手続きに腹を立てます が、あなたはこの仕事が好き ですか ?

助成金申請事務はとてもおも しろい仕事だと思います。お そらく、事態が絶えず変化し ているからだと思います。新 たな支援機関と仕事をし、申 請者も絶えず変わっていきま す。いろいろな人を相手に次々 に対応していくこと、そこが 気に入っています。知的満足 を得られますし、申請を 2 度、 3 度と繰り返して、ようやく助 成金が出るとわかったときの 達成感がたまりません。それ に、私自身がアフリカに出か けてゾウの研究をするわけで はありませんが、そのような 研究が行われていることを知 るのは楽しいものです。

Emma Marris 